\title{
The use of modern technologies in carbon dioxide monitoring
}

\author{
Petr Komínek, Jan Weyr, Jiří Hirš \\ Brno University of Technology \\ Faculty of Civil Engineering, Institute of Building Services \\ e-mail: kominek.p@fce.vutbr.cz, Jan.Weyr@vutbr.cz, hirs.j@fce.vutbr.cz
}

\begin{abstract}
Indoor environment has huge influence on person's health and overall comfort. It is of great importance that we realize how essential indoor air quality is, considering we spend on average as much as $90 \%$ of our time indoors. There are many factors that affect indoor air quality: specifically, inside air temperature, relative humidity, and odors to name the most important factors. One of the key factors indicating indoor air quality is carbon dioxide $\left(\mathrm{CO}_{2}\right)$ level.

The $\mathrm{CO}_{2}$ levels, measured in prefab apartment buildings, indicates substantial indoor air quality issues. Therefore, a proper education of the occupants is of utmost importance. Also, great care should be directed towards technical and technological solutions that would ensure meeting the normative indoor environment criteria, especially indoor air $\mathrm{CO}_{2}$ levels. Thanks to the implementation of new emerging autonomous technologies, such as Internet of Things (IoT), monitoring in real-time is enhanced. An area where IoT plays a major role is in the monitoring of indoor environment. IoT technology (e.g. smart meters and sensors) provide awareness of information about the quality of indoor environment. There is a huge potential for influencing behaviour of the users. Through the web application, it is possible to educate people and ensure fresh air supply.
\end{abstract}

Key words: carbon dioxide, indoor air environment, monitoring, internet of things, smart sensors, people behaviour

\section{Introduction}

According to [1], about $35 \%$ of all buildings are 50+ years old. Therefore, there is an enormous challenge mitigating energy consumption in existing buildings. In most cases, the proposed solutions come down to improving thermal properties of the outer shell (envelope) of the building and to replacing the heat/cool source. The benefit of this solution is reducing energy cost and the amount of primary energy. On the other hand, there is the issue of indoor air quality. This topic is often neglected. 
Thus, indoor air quality of currently existing apartment buildings is the main topic of this paper, mainly focused on $\mathrm{CO}_{2}$ levels monitoring throughout the day in selected flat units. The indoor environment has huge influence on person's health and overall comfort. It is of great importance that we realize how essential indoor air quality is, considering we spend on average as much as $90 \%$ of our time indoors. There are many factors that affect indoor air quality: specifically, inside air temperature, relative humidity and odors to name the most important factors [2], [3].

However, indoor monitoring is not a solution. It is only information about the situation in monitored flats. Therefore, some measure should be available which can help improve the indoor environment in the existing apartment buildings. It is obvious that modern HVAC systems with mechanical ventilation and recuperation units would be the best solution. Unfortunately, there are economic situations and technical situations when modern HVAC system is poorly feasible. In this article, a different solution is presented. There are modern communication technologies which can influence the behavior of the users and take advantage of the existing possibilities of the building, such as natural ventilation (opening windows). This solution uses sensors for indoor monitoring, which are equipped with interoperability with the users of the flats via information communication methods, such as web applications, smartphone applications and smart sensors with parameter indicators.

\section{Indoor Environment and Its Requirements}

If we were to take a closer look at various harmful substances that are commonly found in most dwelling, work, and leisure indoor spaces that do in fact affect the indoor environment [4] and considering the means of monitoring their levels [5], $\mathrm{CO}_{2}$ level monitoring would be the most obvious choice. It can be measured with ease and it is also representative enough when it comes to indoor air quality.

Carbon dioxide $\left(\mathrm{CO}_{2}\right)$ is a naturally occurring, odorless, and colorless gas. $\mathrm{CO}_{2}$ is also formed as a byproduct of burning hydrocarbon fuels, as well as a product of respiration. Concentration levels of $\mathrm{CO}_{2}$ are typically measured in parts per million (ppm). For occupied indoor spaces, $1000 \mathrm{ppm}$ is considered the upper boundary, also known as Pettenkofer criterion. Concentrations above this imaginary boundary can cause sleepiness and impression of stale air, build-up above 2000 ppm can impair the ability to fully concentrate on any given task and can also cause minor headaches. Above 5000 ppm, rapid heartbeat occurs and around $45000 \mathrm{ppm}$ and above leads to unconsciousness and eventually death. Czech legislative requirements considering $\mathrm{CO}_{2}$ levels are listed, among others, in the regulation number $268 / 2009$, specifically $\S 11$ paragraph 5 stating that $\mathrm{CO}_{2}$ is to be considered a benchmark of indoor air quality and should not be allowed to build up above $1500 \mathrm{ppm}$ level [6]. There are various measuring methods and devices used when assessing occupied indoor environment quality (mainly $\mathrm{CO}_{2}$ levels) [7], [8].

\section{Problem with High Level of Carbon Dioxide}

The measurements were carried out in Nový Lískovec, a city district of Brno. The location is exposed to frequent and quite intense winds. The building of interest is a solitary object, not protected from weather conditions by surrounding buildings or landscape. Design outside 
winter temperature for this location is set at $-12{ }^{\circ} \mathrm{C}$. Current development in the area consists mostly of typified prefabricated apartment buildings (type T06B and 70R/K) constructed during the 60 s through 80 s of the last century. Since the beginning of this century, most of these buildings have gradually undergone refurbishment. Several buildings and apartments within them that have already undergone refurbishment at some point were chosen for indoor environment quality monitoring. All of the selected buildings underwent thermal characteristics improvement of the outer shell (envelope) coupled with windows and doors replacement. Energy performance class index for all the buildings is classified as category $\mathrm{C}$. All the buildings are naturally ventilated via openable windows.

Nový Lískovec city district is included as a pilot project location in smart regions project [9], covered by TAČR - Technology agency Czech Republic. Thus, long-term measurements and new technologies are conducted in this particular location and smart city concepts are implemented here.

\section{1 $\mathrm{CO}_{2}$ Monitoring}

The main goal of the monitoring process was to demonstrate that $\mathrm{CO}_{2}$ levels in dwelling spaces generally exceed the tolerable boundaries. Indoor air temperature and relative humidity were also monitored alongside the $\mathrm{CO}_{2}$ levels. The monitoring was carried out from January through April 2015. The timestep of each measurement was set at $15 \mathrm{~min}$. The measuring devices were situated according to recommendations [10] in such a way that the measurements would not be affected by its surrounding environment.

For this particular measurement, an apartment was selected, typical apartment arrangements in this location. Apartment layout is $4+1$ and is occupied by 6 persons, 2 of which are adults and the rest are children.

\subsection{Result of Monitoring}

The monitoring results are indicating issues with $\mathrm{CO}_{2}$ levels exceeding the normative levels allowed for dwelling spaces. The following chart (Fig. 1) showcases how the $\mathrm{CO}_{2}$ levels changed throughout a typical day, in living room of the apartment.

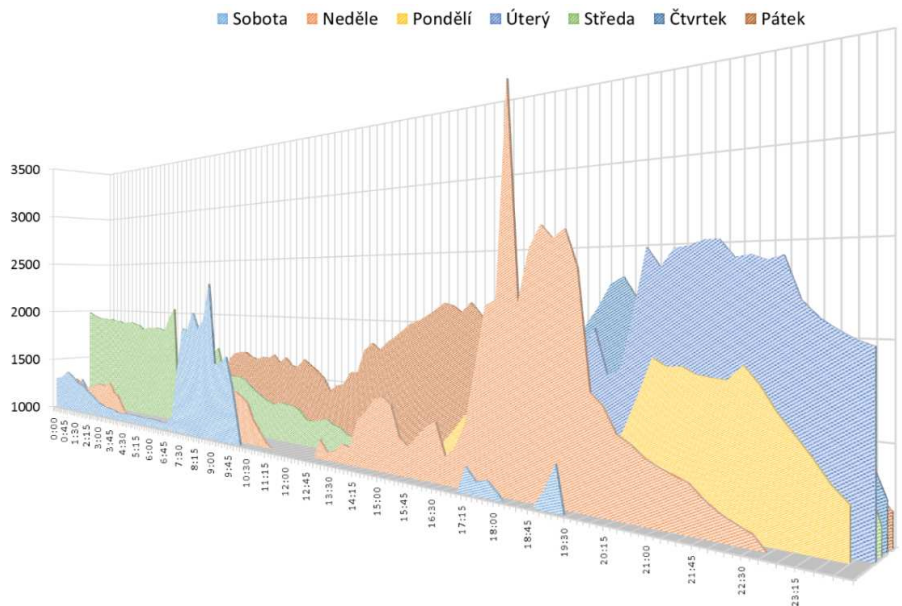

Figure 1: $\mathrm{CO}_{2}$ levels in apartment nr.1 throughout typical week 
The data show substantial exceeding of the normative $\mathrm{CO}_{2}$ levels (1500 ppm according to regulation 268/2009). In some cases, the $\mathrm{CO}_{2}$ levels reach as high as $3500 \mathrm{ppm}$. Generally, the $\mathrm{CO}_{2}$ levels meet the norm only at times of low to no occupancy, due to external air infiltration.

It is imperative to realize that the problems occur in certain time intervals when the rooms/apartments are occupied by their inhabitants. Therefore, the $\mathrm{CO}_{2}$ levels are of interest to us, mainly during these time intervals of full or near full occupancy. Human breath air (average adult man) contain 35000 to $50000 \mathrm{ppm}$ of $\mathrm{CO}_{2}$ (roughly 100 times more than in outside air). Without sufficient fresh air supply needed to lower the $\mathrm{CO}_{2}$ levels, an accumulation of the $\mathrm{CO}_{2}$ occurs. The following chart (Fig. 2) showcases a typical week day and weekend day in the selected apartment.
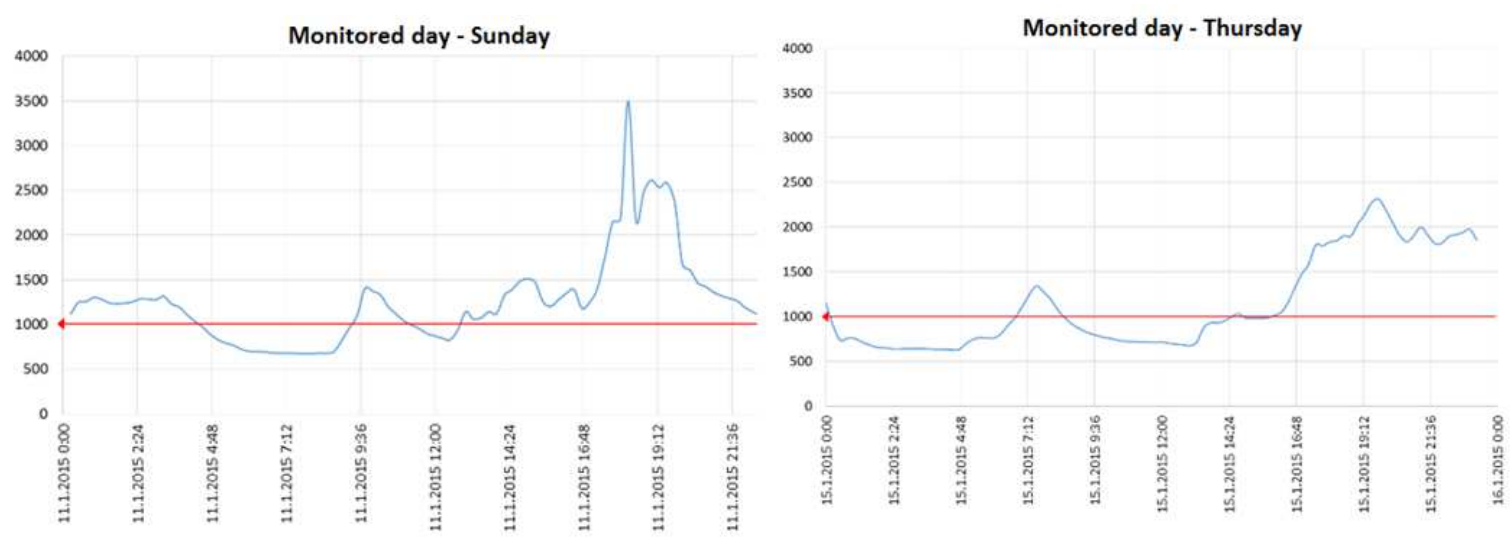

Figure 2: $\mathrm{CO}_{2}$ levels in typical weekend day and week day in the selected apartment

In this case, the monitored room is living room in apartment. It is a common room that serves as a place in the apartment where people (inhabitants and visitors) gather at certain times of day. The occupancy characteristic has direct impact on the $\mathrm{CO}_{2}$ levels. The aforementioned chart (Fig. 4) corresponds to the theory as the highest $\mathrm{CO}_{2}$ levels are reached in late afternoon and evening hours when people return home from work, school etc.

The following table (Table 2) portrays the relation between $\mathrm{CO}_{2}$ levels and fresh outside air supply required to lower the $\mathrm{CO}_{2}$ levels to a certain value. The $\mathrm{CO}_{2}$ level values in this table are approximations based on a simplified concept that consists of an adult person producing $\mathrm{CO}_{2}$ at a constant rate. Furthermore, we consider a constant indoors air change rate (constant outside fresh air supply), constant outside air $\mathrm{CO}_{2}$ level of $380 \mathrm{ppm}$, and also ideal air mixing. Obviously, the real conditions will differ from these assumptions and will be far less predictable.

Table 1: Outside air supply volume needed to achieve specific $\mathrm{CO}_{2}$ level

\begin{tabular}{|c|c|c|c|}
\hline $\begin{array}{l}\text { Koncentrace } \\
\text { CO2 v interiéru }\end{array}$ & $\begin{array}{c}\text { Př́vod čerstvého } \\
\text { vzduchu (m3/h na } \\
\text { osobu) }\end{array}$ & $\begin{array}{c}\text { Rozdil CO2 } \\
\text { (venkovni/vnitřní) }\end{array}$ & $\begin{array}{l}\text { Odpovídá výměně vzduchu } \\
\text { mistnosti } 5 \times 5 \times 2,8 \mathrm{~m}\end{array}$ \\
\hline 800 ppm & 34 & 500 ppm & $0,5 /$ hod \\
\hline 1000 ppm & 25 & 650 ppm & 0,4 /hod \\
\hline 1400 ppm & 17 & $1050 \mathrm{ppm}$ & 0,2 /hod \\
\hline 2400 ppm & 8 & 2050 ppm & $0,1 /$ hod \\
\hline
\end{tabular}


There are many variables changing in time under real conditions, such as occupancy, exhale breath air $\mathrm{CO}_{2}$ levels, outside weather conditions, outside fresh air supply rate etc. that have more or less direct impact on the resulting $\mathrm{CO}_{2}$ levels, air mixing, and many other factors. Due to this ever changing nature, the possibly most effective solution would be to measure the $\mathrm{CO}_{2}$ levels in the monitored room and adjust the room ventilation accordingly, regardless of the utilized ventilation method (mechanical or natural). Natural ventilation should be carried out utilizing full open-able area of the window for a short period of time (5-10 mins). The question is how to make people ventilate. In many flats, there are no indicators of $\mathrm{CO}_{2}$ concentration. People are often uninformed about the problem with indoor air quality. The first level of the measure is informing and educating users. The second level is a sensor with real data. And the third level is HVAC system which solves the problem automatically. The last level is very often unavailable for a reasonable price and technical problems with the implementation.

In many cases, the smart sensor solution with user interaction is sufficient, see Figure 3 . There should be an automatic system which evaluates the level of $\mathrm{CO}_{2}$ concentration. It can be external application in a smartphone, an application on the website or a smart meter with evaluation process and concentration indicator which communicates with users.

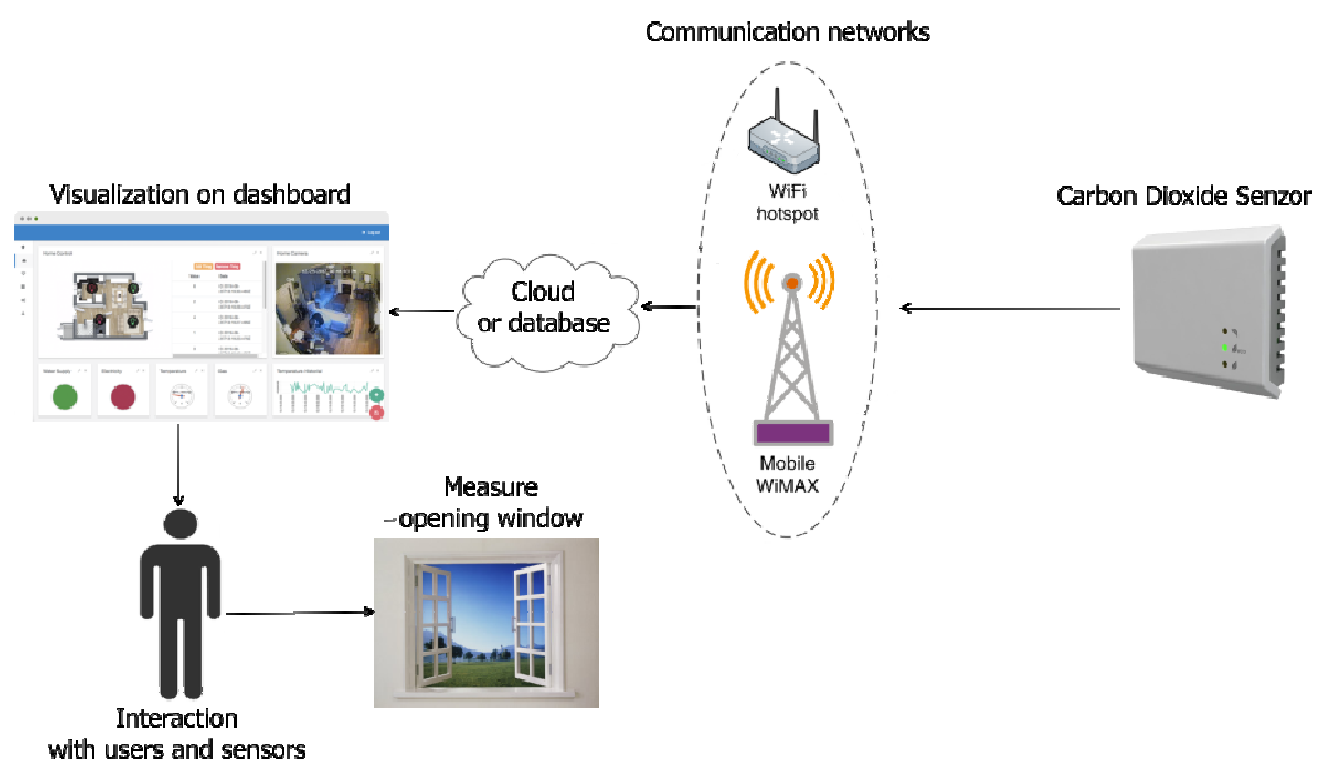

Figure 3: Smart solution

\section{Communication Technologies and Awareness}

In the following section of this article is presented a new approach how to collect data from devices such as sensors and metres and how to visualize this data. The new approach is the Internet of Things.

The Internet of Things paradigm promises to increase the visibility and awareness of data from monitoring thanks to smart sensors and smart meters. Consequently, real-time data from sensors can be collected easily and then analyzed to improve data-aware decision-making. 


\subsection{IoT}

The Internet of Things (IoT) was first used in 1999 by Kevin Ashton [11]. Immediately a technological revolution was expected. This fact is supported by billions of connected devices; in 2008 the number of the devices reached the number of people on the Earth. It is expected to have the same or even larger impact than the Internet itself. It is estimated that in 2020, 26 billion objects will be connected to the internet.

The Internet of Things paradigm is defined as connecting things together via the Internet. Things mean everything that surrounds us and can communicate or not. It is the interplay of smart things and of smart communication networks. The flow of information and events generated by things can be used to facilitate their tracking, management, control and coordination.

\subsubsection{Testing IoT Devices with New Connectivity}

Energy efficiency of battery-running is the main requirements for using IoT devices [12]. Lifetime of various devices such as sensors is essential. There are emerging new communication networks. They include mainly small devices such as sensors and mobiles for long time duration. The success of these networks relies on the availability, low costs, low energy demand, long range, and ease of use. Many communication technologies are present in the literature [13][14].

One of the new communication networks with long range is Sigfox network. It is radio technology that is based on Ultra Narrow Band (UNB) for communication purpose [15]. The network uses license-free spectrum band, in Europe $868 \mathrm{MHz}$ and in the USA $902 \mathrm{MHz}$ (based on regional regulations) [15]. Signal transmission is at a distance of up to $120 \mathrm{~km}$ in open terrain. The used energy in this network is extremely small in comparison with cellular networks, e.g. 50 microwatts as compared to 5000 microwatts in cellular networks [15]. On the one hand, there are low energy demands but, on the other hand, there is a data limit to only 100 bps. It can be a disadvantage but, for many IoT devices (such as $\mathrm{CO}_{2}$ sensors), it is suitable. IoT devices connected through the SigFox network only use the network when they actually require to transmit data; in this procedure, much of the power consumption is reduced [15]. The SigFox network is starting in the Czech Republic. Commercial operation was launched this year.

\section{Case Study}

The same flat in the apartment building as previously was selected. The previous results show problems with an increasing carbon dioxide level. In this case study, a measure how to improve indoor air quality is presented. It is a new approach when the measure is implemented by the users.

The flat was equipped with IoT smart sensors, see Figure 4. These sensors provide real time data visibility via a web application. This application was developed for this case study. For this sensor was used real-time monitoring and through a digital signal sending data to Sigfox storage cloud. The processed data are sent via SigFox network protocol from the $\mathrm{CO}_{2}$ sensor. The sensor is equipped with a ready to use radio transmitter that can be used to send 
information from smart devices into the Sigfox storage cloud which serves as a database. For visualization, a web application was developed which is available on the internet.
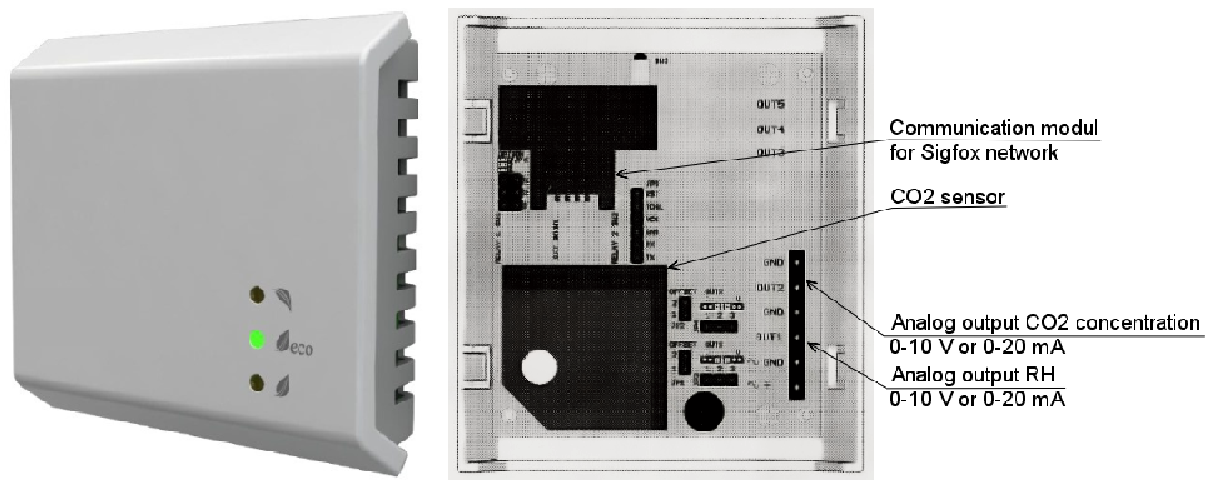

Figure 4: Smart sensor

As a vizualization for data was developed a web application (Figure 5). This application allows the display of the measured data from the sensors. Further, it has an evaluation process which evaluates the critical value, e.g. when the $\mathrm{CO}_{2}$ concentration increases above 1500 ppm, the application reports an overflow by mark diode red. Thanks to this application, the users may react to the current values and improve the indoor climate quality. There are additional possibilites such as educating users, current infromation in indoor climate problematics and other measures. This additional information educates users and ensures interaction of the user and the indoor climate quality. Of course, there is a need to engage with the users because the measures are implemented through the user. It can be an easy and cheaper solution than the new complex HVAC system.

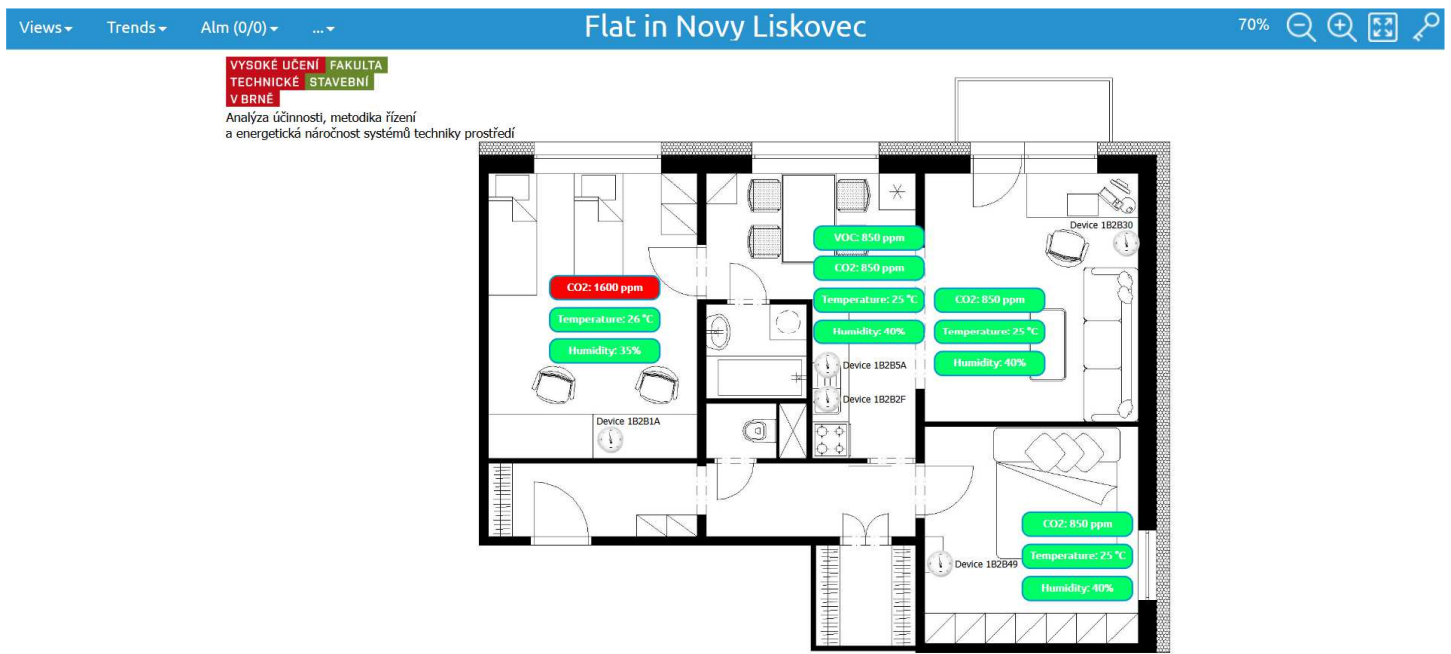

Figure 5: Visualization web application

\section{Conclusion}

In this paper, the measurement of indoor air quality in an apartment flat was presented. The measured concentration of $\mathrm{CO}_{2}$ in the selected apartment was often exceeded and pointed to 
the problem of the quality of the indoor environment in this type of flats. The normative $\mathrm{CO}_{2}$ levels (1500 ppm according to the Czech regulation 268/2009) are being severely and frequently exceeded in the indoor air of refurbished buildings not equipped with mechanical ventilation systems. High levels of $\mathrm{CO}_{2}$ are directly related to the presence of people in the monitored indoor space. There is obvious close synergy between the apartment inhabitants and the indoor air quality. Therefore, educating and providing information to the occupants is of utmost importance.

In this article, a new approach was presented how to educate and inform users by IoT technologies, such as smart sensors. IoT technology provides the users with data and raises their awareness of the issue. There is huge potential for influencing the behaviour of the users. Through the web application, it is possible to educate people and ensure fresh air supply.

In the case study, in the selected apartment, there were situated IoT smart sensors with conectivity through an IoT Communication network, which was recently implemented in the Czech Republic. The measured data are being sent to the storage cloud and visualized by a web application which was developed as part of a research project (nr. FAST-J-14-2527). The users of this apartment are informed about their indoor air quality and they may take measures, such as open the window.

Further work will focus on continuing to monitor $\mathrm{CO}_{2}$ concentrations and how it is influenced by users, who will be provided with information about indoor air quality.

\section{Acknowledgements}

This article has been supported by the project "FAST-S-17-4054 Efficiency analysis, management methodology and energy performance of environmental engineering systems" of the specific research of the Faculty of Civil Engineering and Competence Centres programme of the Technology Agency of the Czech Republic, project No. TE02000077 "Smart Regions - Buildings and Settlements Information Modelling, Technology and Infrastructure for Sustainable Development".

\section{References}

[1] EUROPEAN COMMISSION. Available: https://ec.europa.eu/energy/en/topics/energyefficiency/buildings

[2] JELÍNEK, Vladimír a LINHARTOVÁ Vladimíra. Interní mikroklima v bytových domech. TZBinfo [online]. 2014. [cit. 2015-11-02]. ISSN 1801-4399. Available: http://vetrani.tzbinfo.cz/vnitrni-prostredi/11888-interni-mikroklima-v-bytovych-domech

[3] RUBINA, Aleš, RUBINOVÁ, Olga. Vnitřní prostředí a tepelná pohoda člověka. TZB-info [online]. 2005. [cit. 2015-11-01]. ISSN 1801-4399. Available: http://www.tzb-info.cz/2650vnitrni-prostredi-budov-a-tepelna-pohoda-clovekaAddlesson, L., Rice, C. Performance of Materials in Buildings. Butterworth-Heinemann Ltd, Oxford, 1995.

[4] HAVEL, Milan. Vnitřní prostředí staveb a chemické látky. TZB-info [online]. 2005. [cit. 201511-01]. ISSN 1801-4399. Available: http://stavba.tzb-info.cz/podlahy-pricky-povrchy/11134vnitrni-prostredi-staveb-a-chemicke-latky

[5] CALÌ, D., MATTHES, P., HUCHTEMANN, K., STREBLOW, R. a MÜLlER, D. CO2 based occupancy detection algorithm: Experimental analysis and validation for office and residential buildings. Building and Environment [online]. 2015, 86: 39-49 [cit. 2015-11-04]. Available: http://linkinghub.elsevier.com/retrieve/pii/S0360132314004223 
[6] Vyhláška č. 268/2009 Sb. o technických požadavcích na stavby se změnami: 20/2012 Sb.

[7] GAO, J., WARGOCKI, P., WANG, Y. Indoor Air Quality and Thermal Environment in Classrooms with Different Ventilation Systems. REHVA European HVAC Journal [online]. 2014, vol. 51, p. 10-14. [cit. 2015-11-02]. ISSN 1307-3729. Available: http://www.airtradecentre.com/downloads/AA/Rehva/rehva-newsletter-4-2014.pdf

[8] DU, L., PRASAUSKAS, T., LEIVO, V., TURUNEN, M., PEKKONEN, M., KIVISTE, M., AALTONEN, A., MARTUZEVICIUS, D. a HAVERINEN-SHAUGHNESSY, U. Assessment of indoor environmental quality in existing multi-family buildings in North-East Europe: Experimental analysis and validation for office and residential buildings. Environment International [online]. 2015, 79: 74-84 [cit. 2015-11-04]. Available: http://linkinghub.elsevier.com/retrieve/pii/S0160412015000513

[9] RADA PRO VÝZKUMU, VÝVOJE A INOVACÍ. TE02000077 - Inteligentní Regiony Informační modelování budov a sídel, technologie a infrastruktura pro udržitelný rozvoj (20142019, TA0/TE) [online]. [cit. 2015-11-10]. Available: https://www.isvav.cz/projectDetail.do;jsessionid=17BCAED1731F2C38B97569EEB6018862?

[10] Protronix s.r.o. DOPORUČENÍ PRO UMÍSTĚNÍ ČIDEL KVALITY VZDUCHU [online]. [cit. 2015-11-10]. Available: http://www.cidla.cz/cz/cidla-co2/?novinka=doporuceni-pro-umistenicidel-kvality-vzduchu

[11] Atzori, L., Iera, A., \& Morabito, G. (2010). The Internet of Things: A survey. Computer Networks, 54(1), 52787-52805.

[12] Li, Geoffrey Ye, et al. "Energy-efficient wireless communications: tutorial, survey, and open issues." IEEE Wireless Communications 18.6 (2011): 28-35.

[13] NAIT-SIDI-MOH, Ahmed a Marcelo Dias de AMORIN. Geopositioning and mobility. Hoboken, N.J.: John Wiley and Sons Inc., 2013. Networks and telecommunications series. ISBN 978-1-84821-567-2.

[14] DAR, Kashif, et al. Wireless communication technologies for ITS applications [Topics in Automotive Networking]. IEEE Communications Magazine, 2010, 48.5: 156-162.

[15] ALI, Anum, Ghalib A. SHAH a Junaid ARSHAD. Energy efficient techniques for M2M communication: A survey. DOI: 10.1016/j.jnca.2016.04.002. ISBN 10.1016/j.jnca.2016.04.002. Dostupné také z: http://linkinghub.elsevier.com/retrieve/pii/S1084804516300467 